\title{
Investigation of Vendor Satisfaction Towards Electronic Procurement Website Quality: Case Study of PT. Jasa Marga (Persero) Tbk Project of Surabaya-Gempol Branch
}

\author{
Berto Mulia Wibawa $^{1}$, Oryza Na'afidamara ${ }^{1}$, Dewie Saktia Ardiantono ${ }^{1}$ \\ ${ }^{I}$ Department of Business Management, Faculty of Creative Design and Digital Business, Institut Teknologi Sepuluh \\ Nopember (ITS), Surabaya 60111, Indonesia
}

*Corresponding author. Email: oryzadamara@gmail.com

\begin{abstract}
Recently, website service quality is one of the crucial aspects of communicating with partners. Increasingly complicated procedures, administrative, and shorter time, make vendors have a problem when using an electronic website of government instituted called LPSE (Layanan Pengadaan Secara Elektronik). While the vendor has not been asked directly for their experience in using LPSE. In this case, Jasa Marga LPSE website has not been evaluated yet. Further, this study aims to analyze the relationship between LPSE website quality with vendor satisfaction. The variables used in this study are usability, information quality, service interaction, and user satisfaction. This study is conclusive descriptive multiple cross-sectional with the sampling technique is the saturation sampling. Data collection was carried out through telephone interviews to 62 vendors of LPSE Jasa Marga Surabaya-Gempol. Hypothesis testing is done using multiple regression. The findings of this study indicate that the information quality, usability, and service interaction quality has a positive and significant relationship to user satisfaction. In Multiple Regression Analysis, there is a finding that from the three variables of this research, the information quality variable has the most significant impact on user satisfaction variable. This study also formulates managerial implications that can be applied by PT. Jasa Marga (Persero) Tbk and LPSE East Java as well. Moreover, the improvement of quality and performance of LPSE's website can be done by giving training to all LPSE admin tender, set a user manual to use Jasa Marga's LPSE's website, and create vendor comments and reviews.
\end{abstract}

Keywords: E-procurement, LPSE Website, Multiple Regression Analysis, PT. Jasa Marga (Persero) Tbk, Vendor's satisfaction.

\section{INTRODUCTION}

\subsection{Research Background}

The rapid development of information and communication technology (ICT) and information systems (IS) makes an opportunity for businesses to change their business patterns from paper-based (conventional) to electronic-based (e-business) [1]. The Indonesian government used this in developing egovernment systems. The implementation of egovernment is expected to increase efficiency and transparency in all business processes carried out by business actors.

On January 25, 2013, the President of the Republic Indonesia issued Presidential Instruction (Inpres) 
Number 1 of 2013, which required all Ministries/Institutions/Institutions to use electronic auctions [2]. One of them is PT. Jasa Marga (Persero) Tbk. PT. Jasa Marga (Persero) Tbk, who first implemented e-procurement activities using electronic procurement, namely LPSE (Layanan Pengadaan Secara Elektronik) website in 2014.

Based on previous research conducted in 2019 with 20 vendors, 275 vendors registered themselves at Jasa Marga LPSE [3]. However, only 75 vendors or 27 percent of vendors participated in the prequalification process. By research it was shown that the vendor was not satisfied with the quality of Jasa Marga's LPSE website due to the vendor having difficulty contacting the helpdesk, uploading files late, and lack of understanding of the eauction flow at Jasa Marga's LPSE. As a service company, of course PT. Jasa Marga (Persero) Tbk is very dependent on their vendors. Therefore PT. Jasa Marga (Persero) Tbk must maintain the level of vendor satisfaction in order to avoid suppliers scarcity.

\subsection{Problem Identification and Research}

\section{Objective}

Website service quality is one of the crucial aspects of communicating with partners. Increasingly complicated procedures, administrative, and shorter time, make vendors have an obstacles when using an electronic website of government instituted called LPSE (Layanan Pengadaan Secara Elektronik). While the vendor has not been asked directly for their experience in using LPSE. Jasa Marga LPSE website has not been evaluated yet.

The aim of this research are to (1) analyze the characteristics of vendors who follow the e-procurement process at PT. Jasa Marga (Persero) Tbk SurabayaGempol Branch, and to (2) analyze vendor satisfaction determinant towards Jasa Marga electronic procurement (LPSE) website quality.

\section{LITERATURE REVIEW}

\subsection{E-Procurement}

Electronic procurement (EP) has been defined as the use of data and communication technology by governments in conducting their procurement relationship with bidders for the acquisition of products or services and other consulting services needed by the public sectors [4]. [5] indicated that public e-procurement is the core instrument that helps in the economic management of public resources. E-procurement solution helps the government sector units to procure all materials that needed. It helps obtain services and projects the procurement of goods or services using the e- procurement system. Hereafter utilizes the development of communication and information technology to support the procurement process electronically. E-procurement refers to merging information technology systems for procurement functions, including resource searching, ordering, purchasing, and negotiation [4]. The definition of e-procurement, added by [6], is a technology designed to facilitate the procurement of goods or services via the internet.

\subsection{Electronic Procurement Website (LPSE)}

LPSE (Layanan Pengadaan Barang/Jasa Secara Elektronik) is an information technology management service to facilitate the implementation of procurement of goods/services electronically. LPSE is one of the government's e-procurement applications in Indonesia that is managed by Government Goods and Services Procurement Policy Agency called LKPP (Lembaga Kebijakan Pengadaan barang dan Jasa Pemerintah). The purpose of using LPSE is to build a procurement system for goods/services that is more transparent, accountable, improves market access and fair business competition, and improves the efficiency of the procurement process.

Based on the Decree of the Directors of PT. Jasa Marga (Persero) Tbk Number 142/KPTS/2014, the implementation of Jasa Marga's LPSE website began in 2014. The use of Jasa Marga's LPSE as a means of carrying out goods/services procurement activities with a project value above 700 million Rupiah. Jasa Marga's LPSE website address at www.lpse.jasamarga.com.

\subsection{Webqual 4.0}

Webqual method is a method used to evaluate the quality of services and information on a website from the user's perspective [7]. Webqual is one of the most widely used methods for measuring website quality based on the perception of its users [8]. The Webqual method is a development of the Servqual method used to measure service quality. While the research instrument from the Webqual method was developed using the Quality Function Development (QFD) method. This method can be used to analyze the quality of internal and external websites. Webqual 4.0 consists of 3 dimensions, namely usability, information quality, and service interaction. The dimensions of Webqual 4.0 will be shown in Appendix 1 [9].

\subsection{User Satisfaction}

According to [10], the definition of user satisfaction is the response or user response regarding the fulfillment of needs. A product or service is said to affect user satisfaction if the product or service can meet user needs. 
Also, satisfied users are product or service users who have feelings of pleasure or disappointment due to a comparison between the quality of the product or service they feel and expect [11]. User satisfaction describes the success of the information system linked to the elements forming success in several practical and conceptual aspects [12]. Several factors determine the success of an information system, such as usage and perceived usefulness. The dimensions of EUCA (End User Computing Satisfaction) will be shown in Appendix 1 and the literature support [13].

\subsection{Hypothesis}

The hypothesis below shows the second objective of the research to analyze vendor satisfaction determinant towards electronic procurement website quality, illustrated in a research model in Figure 1.

- Usability Quality and User Satisfaction

[14] defines ease of use as a level where someone believes that technology can be easily used. According to [15], the intensity of use and interaction between users and websites can also indicate ease. Users consider the use (usability) of the website before carrying out its activities. Ease of use relates to whether or not its users use the website. Barriers that can occur, such as difficulties in operating a website, less attractive appearance, can reduce user perceptions about the ease of use of websites in conducting e-procurement activities, allowing users to develop dissatisfaction with the website. This attitude will affect user satisfaction.

H1. Usability quality has a positive relationship with user satisfaction.

\section{- Information Quality and User Satisfaction}

The information presented on the e-procurement website should include information about the products and services offered and needed by both parties. to meet vendor needs, product and service information must be up-to-date and help vendors make decisions, be consistent, and easily understand. The more quality the information provided to the user, the higher the user satisfaction will be [16].

H2. Information Quality has a positive relationship with user satisfaction.

- Service Interaction Quality and User Satisfaction

According to [17], interaction is what involves website users as user experience with the website itself. Good quality of service interactions has a reputation, security in transactions, the protection of confidentiality of personal information, and communication with companies [18]. Define by Menon et. al., [19], product quality (service) is one of the parts that are related to creating superior value for customers. The creation of excellent value for customers is a stepping stone for companies to gain a competitive advantage [19]. The critical success factor lies in the good interactions that exist between vendors and companies

H3. Service Interaction quality has a positive relationship with user satisfaction.

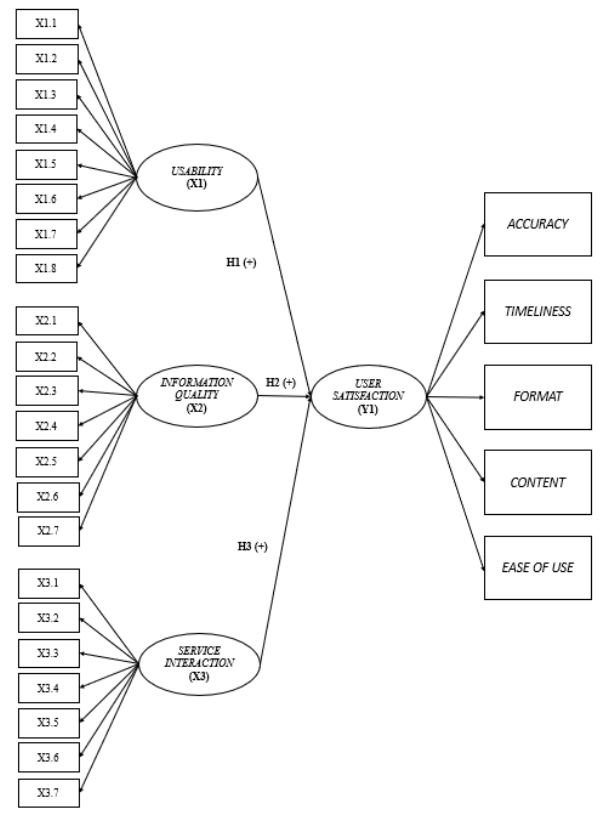

Figure 1. Research Model

\section{RESEARCH METHODS}

This study is conclusive descriptive multiple crosssectional. The technique of collecting data through telephone interviews to 62 vendors of LPSE Jasa Marga Surabaya-Gempol. Appendix 1 shows the measurement items used along with Factor Loading values to test the validity and Cronbach's Alpha for reliability testing. Of all 17 indicators were processed further.

The sampling technique used is saturation sampling, where this technique recruits all of vendors that registered themself on LPSE website. According to [20], a saturated sampling technique is when all members of the population are used as a sample, or it is also called census.

The criteria of respondents in this study were the vendor representatives who were responsible for uploading company files to the LPSE website and registered themself on LPSE website within the last three years, from 2018 until 2020. 
The entire valid data will be processed by Multiple Regression Analysis to answer the second objective of the study, which is to analyze vendor satisfaction determinant towards electronic procurement website quality. The second objective is to know whether or not there are relationship in independent variable which are usability, information quality, and service interaction quality and user satisfaction with the help of the Multiple Regression Analysis test.

\section{DISCUSSION}

\subsection{Descriptive Analysis}

The valid data obtained were 62 respondents. A vendor with a technical admin/administrative position became the majority in this study, namely 52 percent of the total 62 vendors LPSE Jasa Marga Surabaya-Gempol website. As many as 53.2 percent of respondents have used Jasa Marga Surabaya-Gempol LPSE for the past 34 years.

The frequency of respondents in using LPSE Jasa Marga is at least once within three years of 83.9 percent, shows that the e-auction contained in Jasa Marga LPSE website majority is followed by various vendors to improve competitiveness. An average auction amount between 1,1 Billion Rupiah and 7 Billion Rupiah of 61.9 percent. So they are classified as medium companies sort by their company capital. 53 percent of vendors are using LPSE Jasa Marga website for 3-4 years period of time.

Table 1. Descriptive Analysis

\begin{tabular}{|c|c|c|}
\hline Descriptive Analysis & Sum & Frequency \\
\hline \multicolumn{3}{|l|}{ Position in the company } \\
\hline Technical Admin/Administrative & 32 & $52 \%$ \\
\hline Marketing/Marketing Tender & 18 & $29 \%$ \\
\hline Vice President & 4 & $6 \%$ \\
\hline Operation Manager & 3 & $5 \%$ \\
\hline $\mathrm{CEO}$ & 2 & $3 \%$ \\
\hline HR Manager & 2 & $3 \%$ \\
\hline General Manager & 1 & $2 \%$ \\
\hline Total & 62 & $100 \%$ \\
\hline \multicolumn{3}{|l|}{ Duration of use of Jasa Marga LPSE } \\
\hline $1-2$ years & 25 & $40 \%$ \\
\hline $3-4$ years & 33 & $53 \%$ \\
\hline$>4$ years & 4 & $6 \%$ \\
\hline Total & 62 & $99 \%$ \\
\hline \multicolumn{3}{|c|}{ Frequency of using Jasa Marga LPSE over the past 4 years } \\
\hline $1 \mathrm{x}$ & 52 & $84 \%$ \\
\hline $2 \mathrm{x}$ & 5 & $8 \%$ \\
\hline $3 x$ & 1 & $2 \%$ \\
\hline $4 \mathrm{x}$ & 2 & $3 \%$ \\
\hline $5 x$ & 1 & $2 \%$ \\
\hline $6 x$ & 1 & $2 \%$ \\
\hline Total & 62 & $100 \%$ \\
\hline \multicolumn{3}{|l|}{ Average auction amount } \\
\hline 800 Million Rupiah - 1 Billion Rupiah & 17 & $20 \%$ \\
\hline 1.1 Billion Rupiah - 7 Billion Rupiah & 52 & $62 \%$ \\
\hline 12 Billion Rupiah - 15 Billion Rupiah & 12 & $14 \%$ \\
\hline >30 Billion Rupiah & 3 & $4 \%$ \\
\hline Total & 84 & $100 \%$ \\
\hline
\end{tabular}

\subsection{Assumption Test}

Assumption tests, which include outliers test, normality test, linearity, multicollinearity, and homoscedasticity, are needed to conduct a Multiple Linear Regression (MLR) model. An excellent linear regression model is the data whose distribution is normal and free from the occurrence of linearity, multicollinearity, and heteroscedasticity. The results of the MLR assumption test are shown in Table 2. The assumption test results show that all assumptions of the Multiple Linear Regression model can be met so that the Multiple Linear Regression model can be used to test the 
research hypothesis. The results of MLR analysis are shown in Tables 3, 4, and 5.

Table 2. Assumption Test of Multiple Regression Analysis

\begin{tabular}{|c|c|c|c|}
\hline Test & Criteria & Result Test & \\
\hline Outliers & z-score $\pm 2,5$ & $\begin{array}{l}\text { z-score minimum }-1.807 \text { and } \\
\text { maximum }+2.415\end{array}$ & Qualified \\
\hline Normality & $\begin{array}{l}\text { Q-Q Plot indicates that the } \\
\text { distribution of data on each } \\
\text { variable is still around the } \\
\text { normal line }\end{array}$ & normally distributed & Qualified \\
\hline Linearity & $\begin{array}{l}\text { Distribution of points on } \\
\text { scatter plots that do not } \\
\text { form certain patterns }\end{array}$ & $\begin{array}{l}\text { scatter plots do not form certain } \\
\text { patterns }\end{array}$ & Qualified \\
\hline \multirow{2}{*}{ Multicollinearity } & Tolerance $>0.1$ & $\begin{array}{c}\text { Tolerance : USA 0.964, INF } \\
0.977, \text { SERV } 0.974\end{array}$ & Qualified \\
\hline & $\mathrm{VIF}<10$ & $\begin{array}{c}\text { VIF : USA } 1.037, \text { INF } 1.024, \\
\text { SERV } 1.026\end{array}$ & Qualified \\
\hline Homoscedasticity & $\begin{array}{l}\text { Distribution of points on } \\
\text { scatter plots that do not } \\
\text { form certain patterns }\end{array}$ & $\begin{array}{l}\text { scatter plots do not form certain } \\
\text { patterns }\end{array}$ & Qualified \\
\hline
\end{tabular}

\subsection{Multiple Regression Analysis}

Table 3 shows that the Multiple Linear Regression (MLR) model has a coefficient of determination $\left(\mathrm{R}^{2}\right)$ of 0.734 or 73.4 percent. The coefficient of determination is the coefficient that explains the proportion of the influence of independent variables on the dependent variable. It means that the usability (USA), information quality (INF), and service interaction quality (SERV) were able to explain the intention to use LPSE Jasa Marga website by 73.4 percent. In comparison, the remaining 26.6 percent is explained by other variables not yet included in the regression model.

Table 3. Summary of Regression Model

\begin{tabular}{rrrrr}
\hline $\mathbf{R}$ & R Square & Adjusted R Square & Std. Error of the Estimate \\
\hline 0,857 & 0,734 & 0,693 & 0,314 \\
\hline
\end{tabular}

F test as shown in Table 4 shows that the $F$ value of 5.847 with a significance value of 0.000 . This significance value is smaller than the value of $\alpha=0.05$, so it can be concluded that the estimated regression model is feasible to use to explain the effect of the independent variable on the dependent variable.

Table 4. The ANOVA Results

\begin{tabular}{lrrrrr}
\hline Model & Sum of Squares & df & Mean Squares & F & Sig. \\
\hline Regression & 0,330 & 3 & 0,110 & 5,874 & 0,000 \\
Residual & 5,727 & 58 & 0,099 & & \\
Total & 6,057 & 61 & & \\
\hline
\end{tabular}

Regression coefficients on Table 5 explain how the quality of the LPSE Jasa Marga website affects the user's satisfaction. Table 4 shows that all three variables are application quality (usability, information quality, and service interaction quality) has a positive significance value is less than the value of $\alpha=0.05$. It means that the usability, information quality, and service interaction quality significantly influences user satisfaction towards LPSE Jasa Marga website quality.
Based on Table 5 can also form a model equation of Multiple Linear Regression, i.e. $\mathrm{Y}=4.382+0.143 \mathrm{X}_{1}+$ $0.288 \mathrm{X}_{2}+0.124 \mathrm{X}_{3}$, which means usability $\left(\mathrm{X}_{1}\right)$, nformation quality $\left(\mathrm{X}_{2}\right)$, and service interaction quality $\left(\mathrm{X}_{3}\right)$. This result shows that all the hypothesis in this study can be proven that is usability, information quality, and service interaction quality have a positive significant effect on vendor satisfaction 
Table 5. Regression Coeeficient

\begin{tabular}{|c|c|c|c|c|c|}
\hline & B & Std. Error & Beta & $\mathbf{t}$ & Sig. \\
\hline (Constant) & 4,382 & 1,236 & & 2,655 & 0,010 \\
\hline USA & 0,143 & 0,130 & 0,122 & 3,652 & 0,041 \\
\hline INF & 0,288 & 0,174 & 0,138 & 2,709 & 0,000 \\
\hline SERV & 0,124 & 0,168 & 0,102 & 2,144 & 0,036 \\
\hline
\end{tabular}

\subsection{Managerial Implication}

The managerial implications of this research are aimed at PT.Jasa Marga (Persero) Tbk Surabaya-Gempol Branch, LPSE East Java, or both. This is because LPSE website managed by government institution and implemented by PT. Jasa Marga (Persero) Tbk as a public company.

A vendor with a technical admin/administrative position became the majority in this study, namely 52 percent of the total 62 vendors LPSE Jasa Marga Surabaya-Gempol website. On the other hand, usability quality in user satisfaction have a positive significant effect on vendor satisfaction towards LPSE website quality. So it is expected that LPSE website can offer an ease of use. LPSE East Java can provide training use of the LPSE website to the tender admins LPSE each vendor in their order easier to using the LPSE website.

Information quality indicator variables that most influence user satisfaction are "providing accurate information" and "providing reliable information". So PT. Jasa Marga (Persero) Tbk always provide accurate, trustworthy and timely information as promised to avoid a bad image for the company. As a previous research, it was found that from 20 vendors of LPSE Jasa Marga Surabaya-Gempol website, still felt that the information provided by the company was sometimes out of schedule and harm to both parties.

Usability quality indicator variables that most influence user satisfaction are "easy to operate/use" and "provide a positive experience". PT. Jasa Marga (Persero) Tbk and LPSE East Java must give an attention to the ease of use of the LPSE Jasa Marga website. So they can prepare SOP (Standard Operational Procedure) about operate Jasa Marga's LPSE website in the form of a video that was displayed on the website's initial page, so that the e-auction process is more effective and efficient.

For "provide a positive experience", PT. Jasa Marga (Persero) Tbk could give the vendor more role in terms of improving the performance of the Jasa Marga LPSE website by making vendor comments, opinions, or review columns. So they can submit their opinions and suggestion about the actual performance of the LPSE Jasa Marga website. From those opinions and suggestion, the company can conduct a vendor satisfaction survey towards the quality of the LPSE Jasa Marga website.

\section{CONCLUSION}

\subsection{Research Conclusion}

This study's respondents were dominated by LPSE Jasa Marga Surabaya-Gempol vendors who have a job as technical admin, which have been using LPSE Jasa Marga at least once within three years. They also joined an auction with an average amount of between 1,1 Billion Rupiah and 7 Billion Rupiah.

Based on the results of hypothesis testing using Multiple Regression Analysis (MLR), it is shown that the information quality, usability, and service interaction quality has a positive and significant relationship to vendor satisfaction. In MLR, there is a finding that from the three variables of this research, the information quality variable has the most significant impact on vendor satisfaction variable. This study also formulates managerial implications that can be applied by PT. Jasa Marga (Persero) Tbk and LPSE East Java as well. Moreover, the improvement of quality and performance of LPSE's website can be done by giving training to all LPSE admin tender, set a user manual to use Jasa Marga's LPSE's website, and create vendor comments and reviews.

\subsection{Limitation and Further Research}

Subsequent research is expected to enlarge the study's scope by adding new object research, such as adding another branch company of PT. Jasa Marga (Persero) Tbk, besides the Surabaya-Gempol branch. Through enlarge the scope of the study, research is expected to be a generalization because of PT. Jasa Marga (Persero) Tbk 
has eight branch companies. Since all public companies have a similar e-procurement website managed by LPSE as a government institution. Subsequent research can also choose another e-procurement website of another public company, such as PLN, Pelindo, etc.

In addition, the next study can make changes to the variable indicators adjusted by research requirements. Webqual 4.0 method has at least 22 variable indicators with three independent variables and one dependent variable. Through adjustment, research is expected to be more specific with their aim of research.

\section{ACKNOWLEDGMENT}

This study was supported by Department of Business Management, Faculty of Creative Design and Digital Business, Institut Teknologi Sepuluh Nopember (ITS). We thank our colleagues from PT. Jasa Marga (Persero) Tbk, Branch of Surabaya-Gempol, for the opportunity and permission to support this research.

\section{APPENDIX}

Appendix 1. Webqual 4.0 Indicator

\begin{tabular}{|c|c|c|}
\hline Indicator Variable Webqual 4.0 & Factor Loading & Cronbach Alpha's \\
\hline \multicolumn{3}{|l|}{ USABILITY } \\
\hline USA1. I discover the LPSE Jasa & & \\
\hline $\begin{array}{l}\text { Marga website is easy to } \\
\text { learn to operate }\end{array}$ & 0,770 & 0,565 \\
\hline USA2. My interaction with the & & \\
\hline $\begin{array}{l}\text { LPSE Jasa Marga website } \\
\text { is clear and understandable }\end{array}$ & 0,636 & \\
\hline USA3. I discover the LPSE Jasa & & \\
\hline $\begin{array}{l}\text { Marga website is easy to } \\
\text { navigate }\end{array}$ & 0,579 & \\
\hline USA4. I discover the LPSE Jasa & & \\
\hline $\begin{array}{l}\text { Marga website is easy to } \\
\text { use }\end{array}$ & 0,539 & \\
\hline $\begin{array}{l}\text { USA5. This LPSE Jasa Marga } \\
\text { website is creates a } \\
\text { positive experience for me }\end{array}$ & 0,535 & \\
\hline \multicolumn{3}{|l|}{ INFORMATION QUALITY } \\
\hline $\begin{array}{l}\text { INF1. LPSE Jasa Marga website } \\
\text { provides accurate } \\
\text { information }\end{array}$ & 0,859 & 0,477 \\
\hline $\begin{array}{l}\text { INF2. LPSE Jasa Marga website } \\
\text { provides believable } \\
\text { information }\end{array}$ & 0,744 & \\
\hline $\begin{array}{l}\text { INF3. LPSE Jasa Marga website } \\
\text { provides timely } \\
\text { information }\end{array}$ & 0,698 & \\
\hline $\begin{array}{l}\text { INF4. LPSE Jasa Marga website } \\
\text { provides relevant } \\
\text { information }\end{array}$ & 0,681 & \\
\hline $\begin{array}{l}\text { INF5. LPSE Jasa Marga website } \\
\text { provide easy to } \\
\text { understand } \\
\text { information }\end{array}$ & 0,657 & \\
\hline $\begin{array}{l}\text { INF6. LPSE Jasa Marga website } \\
\text { provides information at the } \\
\text { right level of detail }\end{array}$ & 0,636 & \\
\hline $\begin{array}{l}\text { INF7. LPSE Jasa Marga website } \\
\text { presents the information in } \\
\text { an appropriate format }\end{array}$ & 0,535 & \\
\hline
\end{tabular}




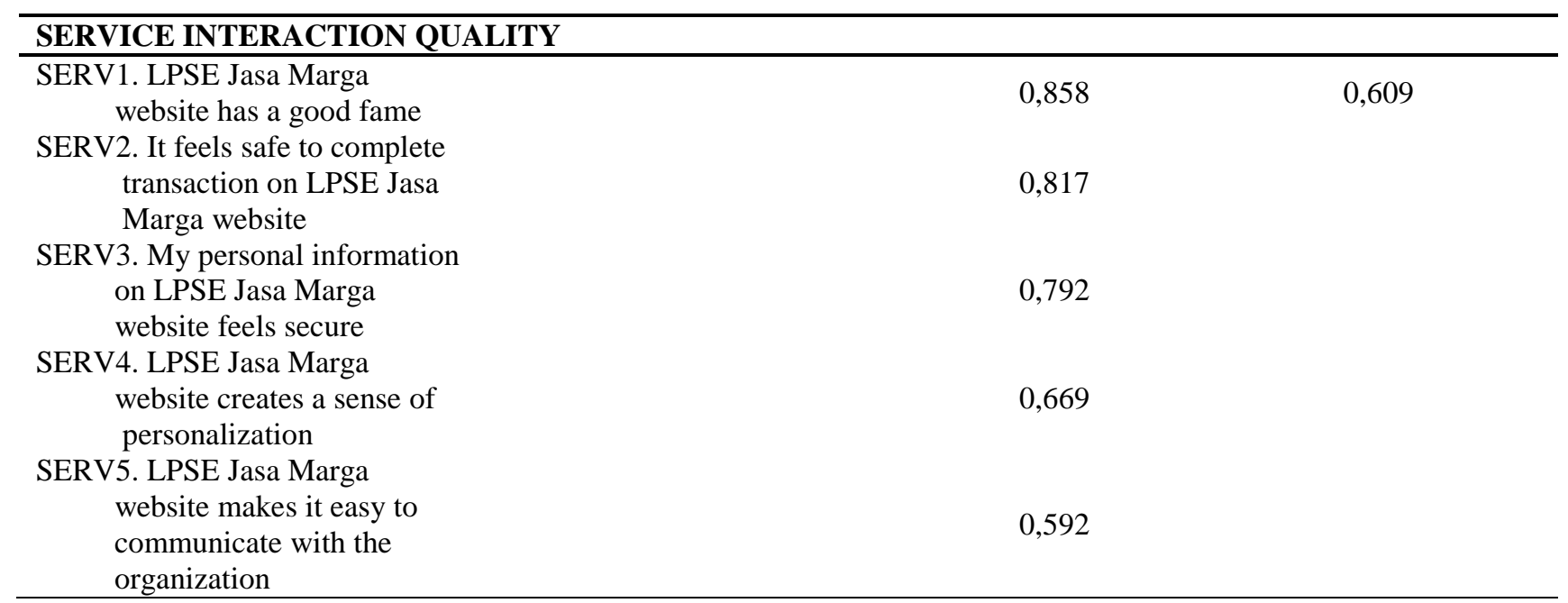

\section{REFERENCES}

[1] Utama, A. S., \& Prabiyanto, A. E. (2019). EProcurement System Pengadaan Barang dan Jasa Pada PT. Trakindo Utama Surabaya . Jurnal Riset Akuntansi dan Bisnis Airlangga. 4(1): 1

[2] Direktori Training Indonesia. (2019). Training Teknik E-Procurement SPSE4. Retrieved from Informasi Seminar dan Training di Indonesia: http://direktoritraining.com/training-teknik-eprocurementspse-4/

[3] Na'afidamara, O. (2019). Measurement of Vendor Satisfaction Towards LPSE Website: Case Study of PT. Jasa Marga (Persero) Tbk SurabayaGempol Branch. Internship Report. Surabaya: Department of Business Management ITS.

[4] Croom, S., \& Brandon-Jones, A. (2007). Impact of E-procurement: Experiences from implementing in the UK public sector. Journal of Purchasing and Supply Management. 13(1): 294-303.

[5] Burton, R. (2005). Improving Integrity in Public Procurement: The Role of Transparency and Accountability, in Fighting Corruption and Promoting Integrity in Public Procurement. OECD Publishing, pp. 23-8.

[6] Davila, A., Gupta, M., \& Palmer, R. (2003). Moving Procurement Systems to the Internet: The Adoption and Use of E-Procurement Technology Models. European Management Journal. 2(3): 1.

[7] Haikal, F. R., Herlambang, A. D., \& Wardani, N. H. (2018). Evaluasi Kualitas Website Dengan Webqual Dan Importance-Performance Analysis (Studi Pada Website Perusahaan Daerah Air Minum Surya Sembada Surabaya). Jurnal
Pengembangan Teknologi Informasi dan Ilmu Komputer. 3(7): 84.

[8] Irawan, C. (2012). Evaluasi Kualitas Website Pemerintah Daerah Dengan Menggunakan Webqual (Studi Kasus Pada Kabupaten Ogan Ilir). Jurnal Sistem Informasi (JSI). 52(1): 488-502.

[9] Shia, B. C., Chen, M., Ramdansyah, A. D., \& Wang, S. (2016). Measuring customer Satisfaction Toward Localization Website by WebQual and Importance Performance Analysis (Case Study on AliexPress Site in Indonesia). American Journal of Industrial and Business MAnagement. 06(02): 117-128.

[10] Zeithaml, V. A., \& Bitner, M. J. (2000). Services Marketing: Integrating Customer Focus across the Firm. Second Edition Hill. New York: McGraw.

[11] Kotler, P. \& Keller, K.L. (2012). Marketing Management, 14 Edition. New Jersey: Prentice Hall

[12] Bailey, J., \& Sammy, W. (1983). Development of a Tool for Measuring and AnalysingComputer User Satisfaction. Management Science. 29(5): 530-545.

[13] Xiao, L. \& Dasgupta, S. (2002). Measurement of User Satisfaction with Web-Based Information Systems: An Empirical Study. Eight Americas Conference on Information Systems.

[14] Davis FD. (1989). Perceived usefulness, perceived ease of use, and user acceptance of information technology. MIS Q 1989. 13(3): 319-39.

[15] Goodwin, N. (1987). Functionality and usability. Communications of the ACM. 30(3): 229-233 
[16] Aditya, A. (2017). Analisis Pengaruh Kualitas Website Terhadap Kepuasan Pengguna Berdasarkan Metode Webqual 4.0 Pada Website www.wingscorp.com. Surabaya: STIKOM Surabaya.

[17] Suyanto, A. H. (2009) Step by Step Web Design Theory and Practices. Yogyakarta: Andi

[18] Barnes, S. J., \& Vidgen, R. T. (2002). An Integrative Approach to the Assessment of E-
Commerce Quality. Journal of Electronic Commerce Research. 3(3): 114-127.

[19] Menon, A., Jaworski, B. J., \& Kohli, A. K.. (1997). "Product Quality: Impact of Interdepartmental Interactions", Journal of the Academy of Marketing Science. 25(3): 187 - 200

[20] Sugiyono. (2010). Metode Penelitian Bisnis. Bandung: Alfabeta. 